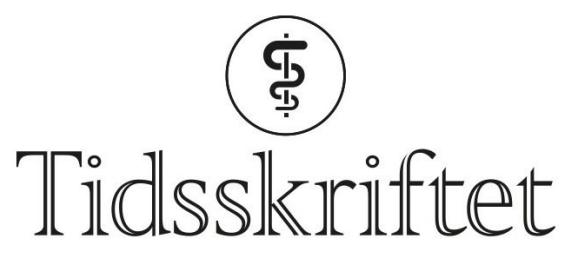

DEN NORSKE LEGEFORENING

\title{
De valgte en trygg død på lokalsykehuset
}

REPORTASJE

\section{LISA DAHLBAK JACOBSEN}

E-post: lisa.dahlbak.jacobsen@tidsskriftet.no Tidsskriftet

- Det lå en slags forventning i lufta, følte jeg, om at Martine burde få dø hjemme og ikke på sykehus, sier Heidi Bunæs Bang, som mistet sin seks år gamle datter Martine til en aggressiv hjernesvulst. De fikk valget mellom å la datteren få dø hjemme eller på sykehus. De valgte sykehuset.

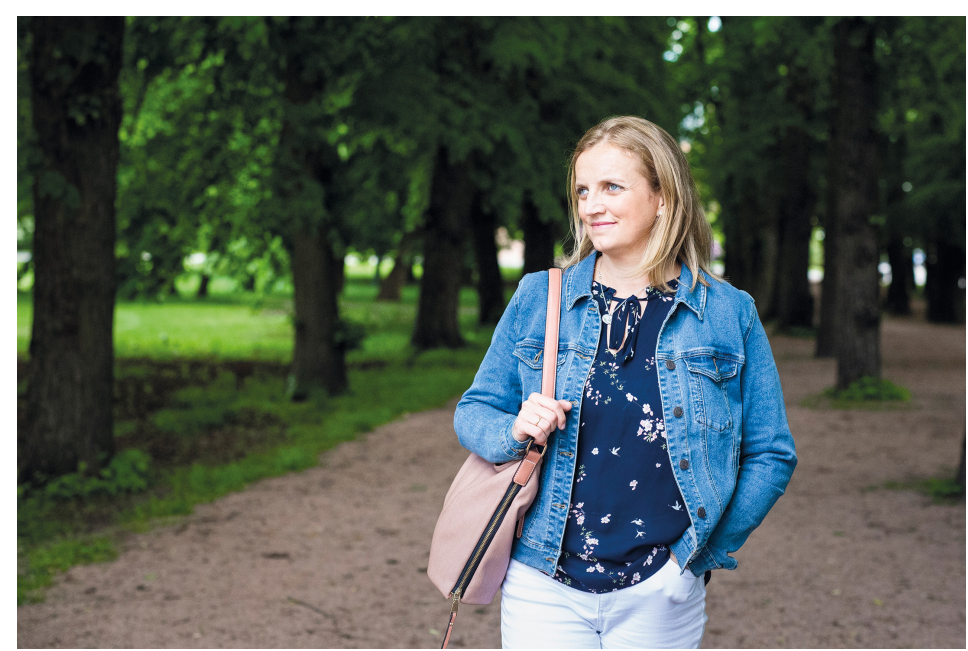

Heidi Bunces Bang har skrevet bok om hele perioden fra de første små symptomene på den aggressive hjernesvulsten viste seg hos datteren, til ett år etter at Martine (6) døde. Foto: Kristine Lindebø

Heidi Bunæs Bang, hennes mann Kristoffer og de to storesøsknene til Martine måtte oppleve det aller verste. Å miste en datter, en søster. Brutalt tidlig.

- Det var rett og slett for vanskelig å være den beste mammaen og pappaen for Martine samtidig som vi skulle være lege, sykepleier og kokk, forteller Heidi Bunæs Bang om den siste tiden før Martine døde.

Lørdag 7. oktober 2017 på Akershus universitetssykehus dør Martine. Da er det knapt to år siden familien fikk den fatale beskjeden. Deres da fire år gamle datter fikk diagnosen ponsgliom, eller diffuse intrinsic pontine glioma (DIPG). Det er en svært aggressiv hjernesvulst som utvikler seg i hjernebroen - pons - i hjernestammen. Plasseringen gjør svulsten umulig å radikaloperere. Det finnes ingen kur, men pasienten behandles med stråling og cellegift, for kortvarig bedring. Median overlevelsestid er ni måneder - og sykdommen rammer i 
hovedsak barn.

Heidi Bunæs Bang valgte å skrive bok om hele sykdomsforløpet fra de første små symptomene til året etter at Martine døde. I boken Nå er dagen over, om å miste det umistelige, utgitt av Gyldendal i februar 2020, skriver hun om hvordan beskjeden om diagnosen og fremtidsutsikten ble gitt. Om hvordan man ble kasteball mellom sykehus. Om hvordan man selv, familien og helsepersonell forholder seg til den kommende døden. Om ønsket om å la være å fortelle en seksåring at hun skal $\mathrm{d} \emptyset$, og at noen leger mente noe annet. Om hvordan kommunikasjonen med, og ikke minst mellom, legene har vært. Om den gode kommunikasjonen, og den svært dårlige. Om fantastiske sykepleiere. Og om hvordan man følte seg gitt opp.

- Ja, litt som et hår i suppa. «Å, lever du fortsatt?», forteller Heidi.

Og om håp. Veldig mye om håp. Om håp som blir fratatt en, og om håpet man tviholder på. Og om det endeløse og fortvilende tapet. Det håpløst naturstridige i å miste barnet sitt.

- Jeg skrev dagbok gjennom hele prosessen. Mest fordi jeg var redd for å glemme alle de små øyeblikkene. Men etter at Martine døde, fikk jeg et behov for å skrive ned mer av historien. Jeg hadde så mange tanker i hodet jeg måtte bearbeide, og jeg var livredd for at hun skulle bli glemt. Da jeg bestemte meg for at jeg ønsket å gi ut boken, var det fordi jeg ønsket å hjelpe andre i lignende situasjoner, slik at de ikke skal føle seg så alene. Jeg ønsket også at de som står rundt, skal få en større forståelse av hva vi med alvorlig syke og døende barn står i. slik at de vet litt hva de kan gjøre for å hjelpe, sier Heidi, og legger til:

- Hovedmotivasjonen min er å spre kunnskap for å få mer forskning på sykdommen, og at det i fremtiden en gang skal finnes noe som forlenger livet til barna.

\section{Forsøk på å være hjemme}

To uker før Martine døde, hadde familien en natt hjemme etter et lengre opphold på sykehuset. De fikk beskjed om at de kunne komme tilbake når de ønsket. I dagboken $\sin 27$. september, som er tatt med i boken, skriver Heidi:

«Jeg våknet brått av at Martine ynket seg. Det var midt på natten og mørkt i rommet. Hun hadde så vondt i nakken. Hun fikk både Paracet og Ibux, men det hjalp ikke. Hvorfor skulle dette skje nå, når vi hadde planlagt å være hjemme litt? Smertene i nakken har vært beskjedne hittil. Men vi vet så altfor godt at kreften har spredd seg raskt nedover i nakken hennes.

Kristoffer ringte til legen som har nattevakt på sykehuset, og jeg fikk vite at det bare var morfin som kan lindre disse smertene. 


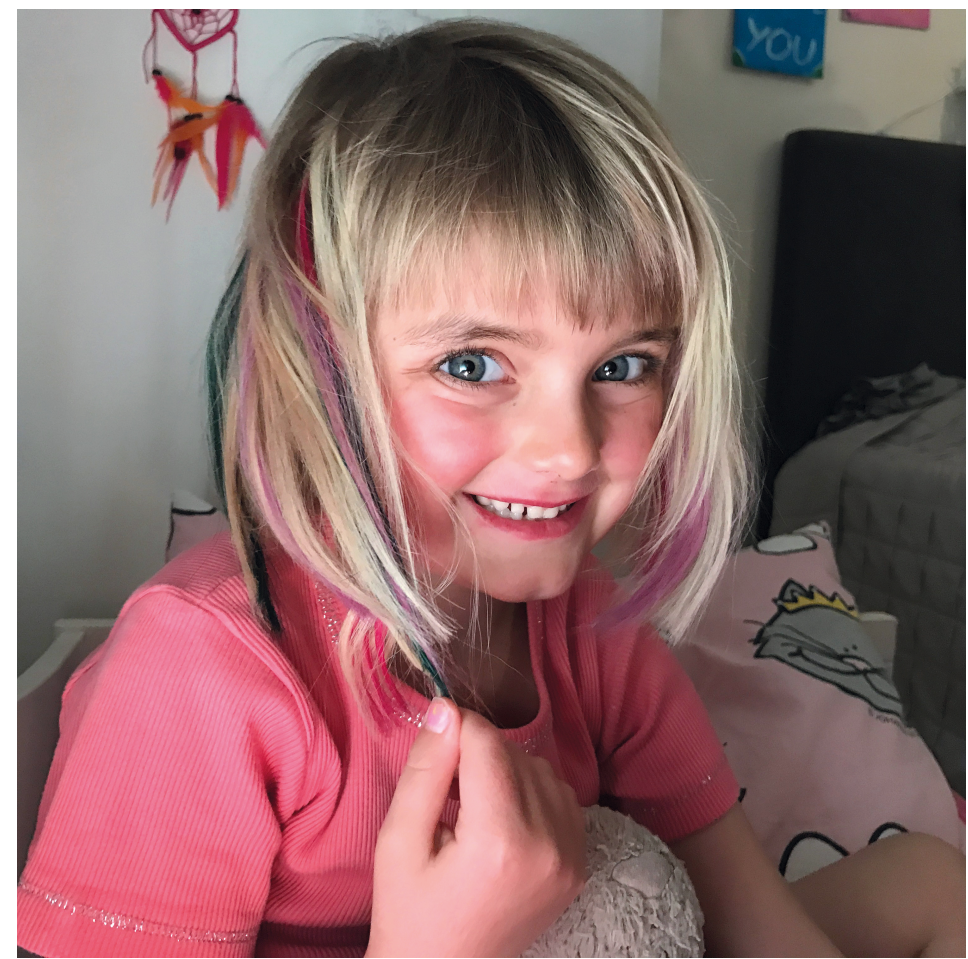

Martine Bunces Bang fikk diagnosen ponsgliom i en alder av fire år. Foto: Privat

Midt i den mørke, kjølige septembernatten kom en ambulanse inn på parkeringsplassen foran huset vårt. Ambulansearbeiderne arbeidet med henne inne på vårt soverom, og scenen som utspilte seg foran meg føltes surrealistisk. Det virket ikke som om de var vant med å gi medisiner i en CVK, og det skapte stor usikkerhet hos oss, men omsider fikk de det til. Morfinen lindret smertene raskt, og Martine var ikke redd.

'De var jo snille', sa hun før hun sovnet. Morfinen virket i fem timer, så grytidlig om morgenen våknet hun med nye smerter. Ambulansearbeiderne måtte komme for å fylle på med mer morfin. Vi ringe legen på Ahus med en gang de kom på jobb den morgenen. Vi kan ikke ha det sånn. Hva vil skje når hun våkner neste gang, med smerter på ny?»

- Jeg var så redd og fortvilet. Skulle virkelig vi ha ansvaret for Martine alene hjemme hos oss? Det lå en slags forventning i lufta, følte jeg, om at Martine burde få dø hjemme og ikke på sykehus. Det bekymret meg veldig. Vi visste jo hvordan det ville ende, men jeg hadde ingen forutsetninger for å forstå hvordan, og jeg ville helst ikke tenke på det. Vi tok en time av gangen. Det var slik vi klarte å komme oss gjennom den siste tiden. Det ble for vanskelig å se langt frem.

Martine og familien hadde i lang tid hatt et tilbud gjennom Avansert hjemmesykehus for barn. De var i gang med å få på plass en ordning for palliasjon, men foreløpig var bistand og en detaljert plan fra kommune og Hjemmesykehuset uavklart.

- Jeg har lest litt om hvor det er best å dø, og det virker som om alle mener at det er best for både barnet og familien å få være den siste tiden hjemme i trygge og kjente omgivelser. Men for oss i vår situasjon ble det vanskelig. Martine hadde så sterke smerter, og så lenge det ikke var en sykepleier eller lege hjemme hos oss hele tiden, var det skremmende. Vi er ikke leger, bare mamma og pappa. Søsknene til Martine var også veldig redde og utrygge. Jeg ønsket ikke at de skulle være redde for å komme hjem fra skolen og så skulle Martine ligge død i sofaen. Det ville blitt veldig traumatisk for dem. Dessuten var ikke Martine redd for å være på sykehuset. Men det var vanskelig å vite hva som var det rette. Vi ville jo gjerne gjøre det som var best for Martine, vi var villige til å strekke oss langt for å få det til.

Hun forklarer at hun trengte trygghet og forutsigbarhet på de få områdene hvor det var mulig.

- Men det var så sårt og vanskelig å snakke om. Jeg hadde skjøvet det foran meg hele tiden. Ville ikke innrømme for meg selv at mirakelet jeg håpet på, uteble. Jeg ville ikke at hun 
skulle dø, og da kunne jeg heller ikke snakke om hvor det skulle skje, ikke sant? spør Heidi retorisk.

- Etter natta hjemme med ambulanse på besøk to ganger var jeg helt skrekkslagen og følte at jeg ikke ville klare dette. Derfor ble jeg veldig lettet da sykepleieren fra Hjemmesykehuset spurte om vi helst ville tilbake på sykehuset, at det var helt greit og opp til oss. Jeg svarte: «Ja, det er det vi vil», mens vi gråt av lettelse og fortvilelse. Samtidig føltes det litt som et nederlag at vi ikke fikset å ha henne hjemme.

En ambulanse ble bestilt, og Heidi som lenge hadde levd i håpet og delvis i fornektelse, måtte innse at Martine trolig hadde vært hjemme for siste gang.

"Jeg løftet Martine opp fra sofaen, og var så forsiktig jeg kunne med nakken som hun hadde så vondt i. Jeg bar henne ut i gangen, og visste med meg selv at dette var den aller siste gangen jeg bar henne ut av huset vårt. Hun ville aldri komme levende tilbake til Oppegård», skriver Heidi i boken.

\section{Tilbake på sykehuset}

Da familien igjen var blitt installert på sykehuset, fulgte ti lange dager der Martine stadig ble sykere og sykere. Etter hvert ble det foreslått å halvere matinntaket hennes, og Heidi lå tett inntil Martine hver eneste natt. To senger ble satt ved siden av hverandre med en dyne i sprekken. En sykepleier våket over dem hele natten, slik at Heidi og Kristoffer kunne få sove litt også.

- Avtalen var at de skulle vekke oss hvis noe skjedde med Martine.

Noen dager før Martine dør har Heidi og Kristoffer et møte med legene.

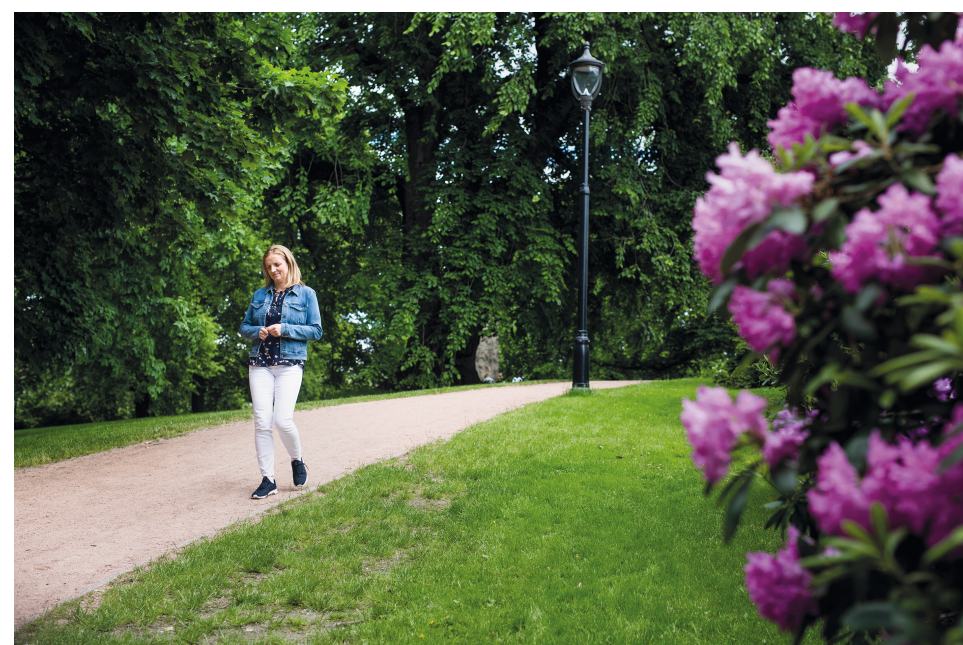

Heidi Bunces Bang fikk erfare at kompetansen på barnepalliasjon i Norge ikke er tilfredsstillende. Foto: Kristine Lindebø

«Dette er vanskelig, men nå synes vi at Martine er blitt veldig mye dårligere. Hun har liten eller ingen livsgnist igjen, vi mener derfor det er best at vi ikke gir henne medisiner lenger. Det vil også være best for henne at vi slutter å gi henne mat og drikke», var beskjeden legene kom med.

I boken sin skriver Heidi:

«Jeg var lamslått. Hvordan kunne de foreslå det? Jeg kunne nesten ikke puste. Det de egentlig sa var at tiden var kommet. De mente at vi nå skulle la Martine dø. Det var ekstremt smertefullt, og jeg opplevde situasjonen som dramatisk. Jeg forsto at dette handlet om grunnleggende etiske spørsmål, men for meg handlet det om ungen min. Hvordan skal jeg forholde meg til en slik beskjed? Hvor mye skal en mamma klare?»

Heidi forteller at hun forsøkte å si at Martine fortsatt klarte å glede seg over noe av det som skjedde rundt henne.

- Hun hadde jo til og med vinket til dem da de kom inn døra på rommet hennes. Men de 
hadde bestemt seg for at tiden var inne. De spurte oss ikke om hva vi mente, men informerte oss om beslutningen sin. Vi hadde nok uansett ikke klart å ta den avgjørelsen selv. Det var greit at vi sluttet å gi henne mat. Vi forsto at fordøyelsen var svært redusert, men at de skulle ta ifra henne all drikken, det nektet vi.

De ble enige om at hun skulle få samme væskemengde blandet med morfin som hun fikk. Solu-Medrol, som holdt hevelsen i hodet i sjakk, den skulle hun derimot ikke lenger få.

- Selv om det er naturstridig for en mor og far å slutte å gi barnet sitt mat og drikke, og beskjeden fra legene hørtes helt grusom og hjerteskjærende ut, måtte vi stole på at legene visste hva som var best for Martine. Vi hadde ikke noe annet valg, sier Heidi og legger til:

- Jeg må stole på at de som har palliativ behandling som fagfelt vet hvordan og når livet skal avsluttes på en mest mulig skånsom måte, uten smerter og på et tidspunkt hvor barnet ikke lenger har noe liv å leve.

Heidi forteller at hun ikke klandret legene for avgjørelsen de hadde tatt for Martine. I boken sin skriver hun at hovedproblemet var at hun overhodet ikke var klar for at den dagen skulle komme.

- Jeg håpet jo fortsatt på et mirakel. Legene fortsatte å snakke om ulike medikamenter som skulle gis mot surkling, panikk og angst. Og jeg kjente at dette klarer jeg bare ikke. Hun hadde akkurat fylt seks år. Det var rett og slett for jævlig.

Lørdag 7. oktober 2017 skriver Heidi i dagboken sin:

«Kristoffer og jeg satt på hver vår side av henne i senga og holdt henne i hånda. Vi sang godnattsanger for henne, og strøk henne over kinnene. Så trakk hun pusten for siste gang. Jeg holdt hånda mi på brystet hennes og kjente at hjertet fortsatte å slå lenge etterpå. Det var laget for å slå i hundre år, ikke bare i seks.»

\section{Vanligere å dø hjemme}

Avansert hjemmesykehus for barn ved Akershus universitetssykehus, som Martine var en av de første palliative pasientene til å benytte, kalles ofte bare Hjemmesykehuset. Ordningen er en av sengepostene i Avdeling for barn og ungdom. De er et lite sykepleierteam som behandler pasienter som enten tidligere har vært behandlet eller innlagt ved sykehuset - og som kan motta polikliniske sykepleiekonsultasjoner hjemme, som blodprøver, tilsyn, medisinering, opplæring og veiledning.

- Vi behandler barn med alle typer diagnoser. Vi er bemannet fra 7 om morgenen til 23 på kvelden. På natten kan familiene kontakte sykepleier i en av sengepostene. Vi ambulerer ikke på natten, forteller Lisa Fosshaug, seksjonsleder for Avansert hjemmesykehus for barn.

Totalt er det syv ansatte, og de har alle minimum fem års erfaring med barn, og mange har også videreutdanning. I utgangspunktet er ikke Hjemmesykehuset et palliativt team, men Barne- og ungdomsklinikken er i 2020 i ferd med å opprette et palliativt team der Hjemmesykehuset har en stor rolle. 


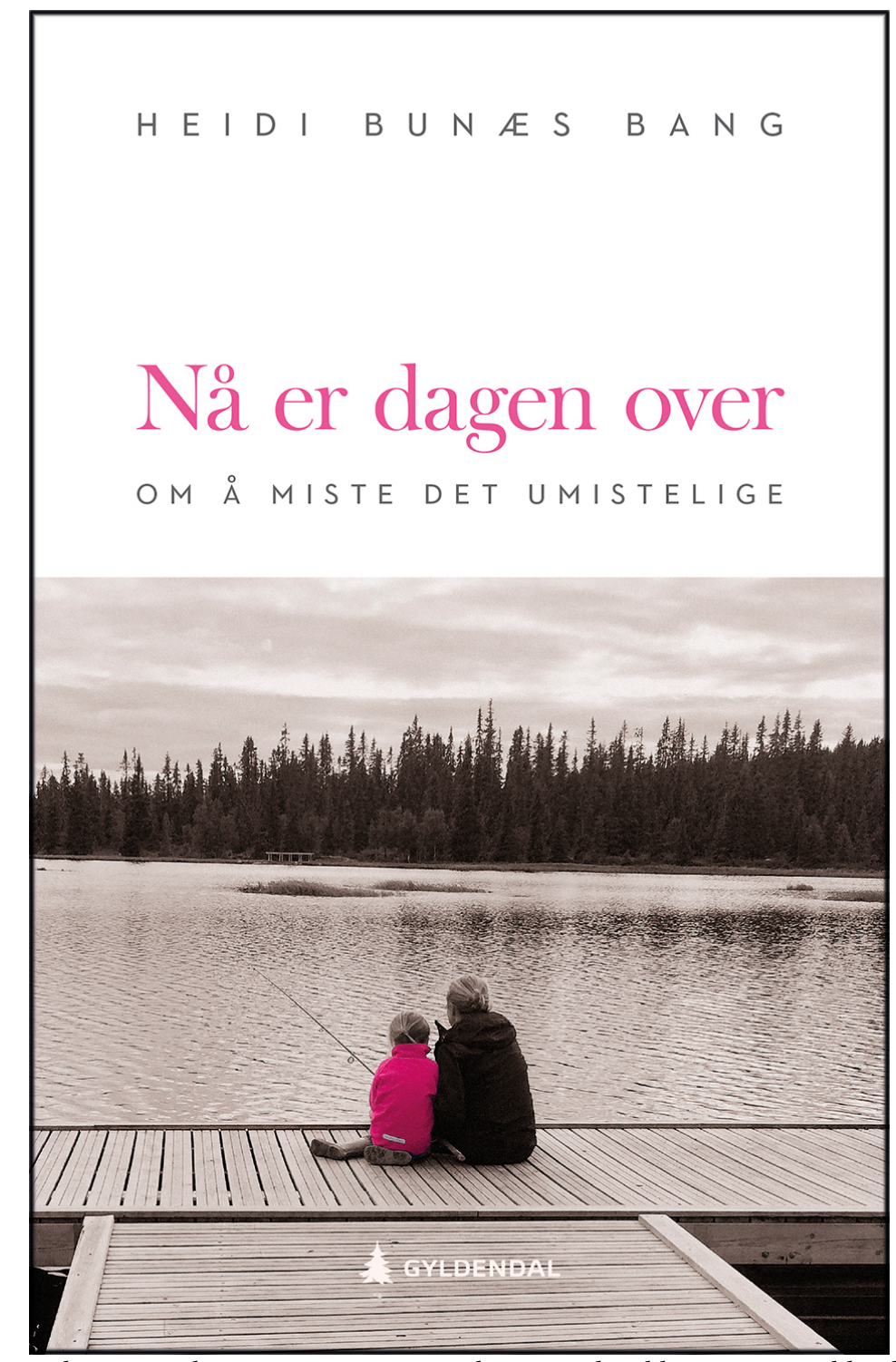

Boken Nå er dagen over, om å miste det umistelige ble utgitt på Gyldendal i februar

- Når vi har fulgt de alvorlig syke barna over lengre tid, vil det være en naturlig del av arbeidet vårt at vi også følger opp når det blir behov for palliasjon og terminal pleie, forteller Fosshaug.

Heidi Bunæs Bang og hennes familie valgte å flytte tilbake til sykehuset for at Martine skulle få dø i trygge omgivelser der. Det er ifølge Fosshaug ikke lenger den vanligste beslutningen.

- Jeg opplever oftest at familiene ønsker at barna skal dø hjemme. Å dø på sykehus er i utgangspunktet en litt gammel tankegang. Men det er viktig å understreke at i $2017 \mathrm{var}$ teamet vårt ganske nyopprettet. Vi hadde ikke fått på plass god nok samordning med kommunene, og vi hadde ikke en plan på plass tidsnok. Vi har lært veldig mye siden oppstarten i slutten av 2015. Nå opplever jeg at flere og flere bruker muligheten for å dø hjemme, sier Fosshaug, og legger til at det er helt essensielt å ha en god plan for livets slutt og et godt samarbeid med familien.

Heidi Bunæs Bang forteller at hun synes sykepleierne ved Hjemmesykehuset gjorde en fantastisk jobb.

- Martine var glad i og trygg på alle sammen. De gjorde alt de kunne for å hjelpe vår familie, gitt de ressursene de hadde på det tidspunktet. Det er veldig positivt at samarbeidet med kommunene er bedre nå og at de fortsetter å bygge opp kompetansen på barnepalliasjon både blant sykepleiere og spesielt leger.

- Man må være i forkant med en god plan, og man må ha et godt samarbeid med kommunen for avlastning på natt og for bistand rundt medisinering. Familiene skal være så 
trygge og forberedt som mulig - så godt det lar seg gjøre i en slik situasjon. Det er viktig at vi skisserer for familiene hvordan de siste dagene før døden kan bli, utdyper Lisa Fosshaug.

Bare det siste året har det blitt opprettet Avansert hjemmesykehus for barn i Bergen og Trondheim, i tillegg til at Stavanger har vært etablert i noen år. Levanger har også et lite poliklinisk tilbud. Mest erfaring med tilbudet har hjemmesykehuset tilknyttet Oslo universitetssykehus, som ble etablert for hele ti år siden.

- Som hjemmesykehus er kommunene en av våre nærmeste samarbeidspartnere. Ved Akershus universitetssykehus har vi enormt mange kommuner og bydeler å forholde oss til, og vi erfarer at samarbeidet er varierende. Ingen er helt likt organisert. Når vi har knekt koden i én kommune, starter vi opp helt på nytt i en annen kommune. Kompetansen i kommunene er også helt ulik.

At barn skal dø hjemme, presiserer likevel Fosshaug, passer ikke for alle.

- Alt skal være tilrettelagt og tilpasset hver enkelt families behov og ønsker. Det er familien som bestemmer hvor barnet skal dø. Smerteproblematikk som ikke kan håndteres hjemme, mange søsken og $ø$ nske fra familien kan være årsaker til at foreldre bestemmer seg for at det totalt sett er best for familien at barnet får dø på lokalsykehuset.

\section{Ingen ekstra midler}

I oppdragsdokumentet til sykehusene blir nå de regionale helseforetakene spesifikt bedt om å etablere regionale barnepalliative team. Ved Akershus universitetssykehus er et lokalt team på vei til å bli etablert. Det skal utgå fra Barneavdelingen og Hjemmesykehuset og skal etter planen startes opp fra høsten.

Det er riktignok ikke bevilget noen penger til lokale barnepalliative team fra regjeringen.

- Det er veldig synd. Vi må omdisponere midler lokalt i klinikken - og å omdisponere betyr å nedprioritere andre viktige områder. Det er trist at det er bevilget 30 millioner til barnehospice og ikke noe til opprettelse av lokale palliative team. Vi sitter med stor kompetanse på hvordan pasientene kan få være hjemme så lenge som mulig, og vi står klare til å gjøre en god jobb for å bygge opp disse palliative teamene. Familiene vi har vært hos, $\emptyset n s k e r$ hjelp til å gjøre tilværelsen hjemme best mulig. Det er viktig å gi tilbud der pasienten bor, påpeker Fosshaug.

Heidi Bunæs Bang sier «ja, takk - begge deler».

- Slik jeg har forstått det, vil et barnehospice være et tilbud og en støtte til hele familien gjennom hele sykdomsperioden, som kan være dager, måneder eller år, og også i tiden etter barnets død. Familier har svært ulike behov, og de trenger all den støtte de kan få.

\section{Kommunikasjon rundt døden}

Teamet på Akershus universitetssykehus vil bestå av barnesykepleiere, psykolog og leger.

- Målet er å bygge kompetanse i hele klinikken. Vi må bli flinkere til å snakke om døden. Vi må tørre å stå i det som også er vanskelig. Samtidig skal man ikke snakke om døden hele tiden. Det er også viktig å fokusere på lysglimtene - på det som er friskt, godt og sunt. Hele helsetjenesten må bli flinkere til å snakke om dette, sier Fosshaug.

- Og hva er din erfaring med legenes kompetanse på feltet?

- Både leger og sykepleiere har behov for å bygge ytterligere kompetanse på dette området. Vi tar oss ikke alltid god nok tid til å samtale med familiene, og mange opplever det krevende å ta opp temaer rundt død og lindrende behandling. Norge har en vei å gå når det kommer til å bygge kompetanse på barnepalliasjon hos leger og sykepleiere, poengterer Fosshaug.

- Vi må jobbe sammen som team. Vi ønsker oss at leger er med på å besøke pasientene i hjemmet. Særlig ved livets slutt. Da kan pasientene slippe å reise inn til sykehuset for 
legetilsyn. Det ville vært en enorm styrke og et godt tilbud til pasienten og familien.

Publisert: 29. juni 2020. Tidsskr Nor Legeforen. DOI: 10.4045/tidsskr.20.0522

(C) Tidsskrift for Den norske legeforening 2020. Lastet ned fra tidsskriftet.no 